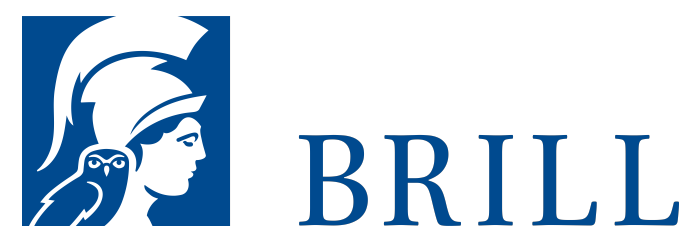

\title{
The Eponymous Priests of Ptolemaic Egypt
}

Chronological Lists of the Priests of Alexandria and Ptolemais with a Study of the Demotic Transcriptions of their Names. With the Assistance of S.P. Vleeming

Authors: Clarysse and van der Veken

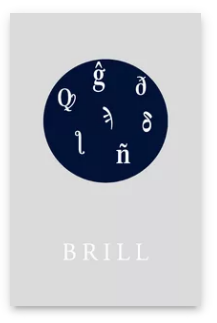

Pages: $\mathrm{x}, 165 \mathrm{pp}$. Language:

English

Subjects:

General,

Classical

Studies,

Codicology,

Papyrology \&

Philology,

Ancient Near

East and Egypt

Publisher: Brill

Series:

Papyrologica

Lugduno-

Batava, Volume:

24

E-Book (PDF)

Released online:

$\mathrm{O} 2 \mathrm{Mar} 2 \mathrm{O} 2 \mathrm{O}$

ISBN: 978-90-

04-42777-8

List price

USD \$189.00

Paperback

Publication date:

o1 Dec 1983

ISBN: 978-90-

O4-06879-7 
For more information see brill.com

Order information: Order online at brill.com +44330 333 0049 | customerservices@brill.com Submission information: brill.com/authors

Titles published by Brill | Fink, Brill | mentis or Brill | Schöningh: +49(o)715413279216| brill@brocom.de 